\title{
Comparative histological study of gametogenesis in diploid and triploid pacific oysters (Crassostrea gigas) reared in an estuarine farming site in France during the 2003 heatwave
}

\author{
Julien Normand ${ }^{1,2}$ Marcel Le Pennec $^{2}$ and Pierre Boudry ${ }^{1, *}$ \\ ${ }^{1}$ Ifremer, Laboratoire de Génétique et Pathologie (LGP), Station de La Tremblade, Avenue du Mus du Loup, \\ 17390 La Tremblade, France. \\ ${ }^{2}$ Institut Universitaire Européen de la Mer, Universite de Bretagne Occidentale, Place Copernic. Technopole \\ Brest Iroise, 29280 Plouzané. France
}

*: Corresponding author : Pierre Boudry, email address : Pierre.Boudry@ifremer.fr, tel: +33 (0)2 9822 44 02, fax: +33 (0)298224653

\begin{abstract}
:
We compared the temporal dynamics of gametogenesis in diploid and triploid Pacific oysters (Crassostrea gigas) using histology. Oysters were reared in an estuarine farming site in Brittany over 3 years and their gametogenesis was monitored over the exceptionally hot summer of 2003. Both diploids and triploids showed active gametogenesis, but a high proportion of triploids remained at early stages of gonad development. Gametogenesis of triploids was characterized by the simultaneous occurrence of gonias and immature cytes together with mature gametes rather than overall retardation, though some triploids showed complete gonad maturation. Evidence of spawning was seen in both groups, and the quantity of germinal products emitted appeared to be similar in triploids and diploids, though triploids were much heavier than diploids. Our study supports previously reported experimental observations and suggests that gonad development in triploid Pacific oysters can be enhanced when these oysters are reared in the field under unusually warm conditions.
\end{abstract}

Keywords: Gametogenesis, Oyster, Crassostrea gigas, Triploidy 


\section{Introduction}

Genetic improvement of Crassostrea gigas through triploidy leads to faster growth (Nell et al. 2005; Garnier-Géré et al., 2002) and reduced gametogenesis (Allen and Downing 1986; Allen and Downing, 1990; Goulletquer et al., 1996). Faster growth rates have been reported for both chemically induced triploid oysters and those produced by diploid $x$ tetraploid crosses. Triploid oysters appear to be at a particular advantage in sites with high trophic richness (Eudeline, 2004). It is very likely that the reduction in gametogenesis contributes directly to the faster growth of triploids compared to diploids, allowing a reorientation of the energetic allocation from reproduction to growth (Allen and Downing, 1986; Hawkins et al., 2000; Honkoop, 2003). The reduction of gametogenesis during the reproductive period also improves marketability of these oysters during the reproductive period (i.e. summer) and limits the propagation of these individuals in natural environment. It should, however, be noted that triploidy is not considered as an efficient method of genetic confinement in oysters (Anderson et al., 2004) since it only leads to partial sterility and because triploids can revert to a diploid stage (Allen et al., 1996; Allen et al., 1999).

Triploid oysters are only partially sterile and retarded gametogenesis of such oysters has been observed in both Humbolt Bay (USA) (Allen and Downing, 1990) and in Tasmania (Gardner et al., 1994 in Nell 2002). Guo and Allen (1994) estimated that relative fecundity of triploid females was around $2 \%$ of the level in their diploid control, with an average of 2.261 million stripped eggs per female in 2-year-old triploid oysters. Despite the lower reproductive potential of triploids relative to diploids, these authors noticed a high variation in reproductive effort between triploid females. While some triploid females had no mature oocytes, others had up to 21 million oocytes that was equivalent to the mean fecundity of the diploid female controls.

In diploid Pacific oysters, gametogenesis is under control of both exogenous signals from environment and endogenous physiological factors. Temperature and photoperiod drive the internal clock of Pacific oysters whilst body condition also influences reproductive development via feedback from other metabolic compartments (Pouvreau et al., 2006; Fabioux et al., 2005; Enriquez-Diaz, 2004; Ren and Ross, 2001). Temperature has long been known as a major factor controlling gametogenesis (Mann, 1979; Chavez-Villalba et al., 2002a, b; Fabioux et al., 2005) and elevation of water temperature stimulates oocyte growth (Chavez-Villalba et al., 2002b). The effect of environmental factors known to control gametogenesis in diploid oysters should be considered in any study of gametogenesis in triploid oysters because effective gametogenesis can occur in triploid Pacific oysters and that individuals exhibit a high variation in reproduction effort.

Following the recent paper by Duchemin et al. (2007), focussing on seasonal variations of immune parameters in diploid and triploid Pacific oysters, the present study further documents the temporal dynamics of gametogenesis in triploid oysters raised in an estuarine rearing site (Aber Belon, South Brittany, France). Our study was performed during the particularly hot and dry summer of 2003, which potentially favoured gametogenesis in triploid oysters.

\section{Material and methods}

\subsection{Biological material and sampling}

Diploid oysters were collected from natural settlement and triploid oysters were purchased from a commercial hatchery thus representing the usual sources of these types of seed cultivated by oyster farmers in France. The triploid oysters had been produced by chemical induction using cytochalasin-B (Allen et al., 1989). Both group of oysters were 3 years old at the beginning of the study (May 2003) and presented a very similar initial mean dry meat weight (DMW) $(1.46 \pm 0.44$ and $1.56 \pm 0.59 \mathrm{~g}$ for diploids and triploids respectively). Oysters were cultured in Aber belon (South Brittany, France) following local practices, off-bottom, using iron frames ('tables') onto wich the oyster mesh bags are attached (Figure 1).

More than fifty individuals from each of the groups were randomly sampled from a large commercial stock twice a month during the intensive gonad maturation period (i.e. from May to July), then monthly from August 2003 to April 2004. Since thirty oysters from both the diploid and triploid groups were 
collected for biometrical measures, a number of individuals comprised between twenty and thirty oysters per group remained for histological preparations and ploidy analysis.

\subsection{Environmental monitoring}

Environmental monitoring was performed during the sampling period by a temperature sensor localized in Riec-sur-Belon close to the farming site where the experimental oysters were reared. The relevant dataset was extracted from the Quadrige database developed by Ifremer (http://www.ifremer.fr/delao/francais/valorisation/quadrige/index.htm) and reflected the exceptional heat experienced in the study area in summer 2003 and its effect on seawater temperature.

\subsection{Biometrical measures}

Dry meat weight and shell weight of 30 individuals from each group (diploid and triploid) were measured to estimate their Walne and Mann condition index (C.I.):

C.I. $=($ dry meat weight $x$ 1000) / shell weight.

Individual shell weight was checked to insure that no significant difference in flesh or shell growth could reveal a sampling bias.

\subsection{Ploidy analysis}

Chemical induction of triploidy rarely produces $100 \%$ triploid batches (Allen et al., 1989). In order to determine the ploidy of individual oysters sampled in the triploid group and exclude diploid individuals from further histological analyses, twenty to thirty oysters from this group were individually tested by flow cytometry until obtaining the twenty triploid oysters for histology using the propidium iodide method, as described by Utting and Child (1994).

\subsection{Histological analysis and cell diameter measurement}

At each sampling point, 20 individuals per group were sampled for histological analysis. A piece of the visceral mass was placed in Bouin's fixative for 48 hours before routine histological processing. Paraffin embedded pieces of tissue were cut into $5 \mu \mathrm{m}$ sections and then coloured with Masson trichrome.

Crassostrea gigas is normally a protandrous alternate hermaphrodite. Microscope observation allowed us to classify individuals as males, females or undetermined. Reproductive stage was determined following a qualitative classification (5 stages: 0 to 4) adapted from Mann (1979) and Lango-Reynoso (2000) (Table 1). These guidelines were based on those originally described for Crassostrea virginica (Kennedy and Battle, 1964 in Mann, 1979).

In order to describe female reproductive stages more precisely, the diameter of germinal cells (LangoReynoso et al., 2000) was measured for 60 cells per female on 10 randomly sampled individuals of each group in June 2003. Histological slides were observed under a microscope at 100X and pictures were recorded with a digital camera (Sony). The pictures were then processed on a Silicon Graphics station using Visilog 5.1 Software. Cell diameter was measured on cells displaying a well defined germinal vesicle, so as to ensure that the section passed through their centre (Lango-Reynoso et al., 2000). The surface of each cell was measured by drawing its diameter on the digital picture in order to calculate its theoretical circular diameter in pixels, and these were then transformed to millimetres following a standard calibration procedure.

\subsection{Statistical analysis}

Statistical analyses were computed using Systat 9. Analysis of frequencies and percentages were treated using Fisher exact tests (two-tails), as described by Sokhal and Rohlf (1995). Comparisons of $\mathrm{Cl}$ and DMW were made using ANOVA, after testing for normality of the dataset with the Levene preliminary test (ANOVA on the absolute values of the residuals, Systat, 1999). Kruskall-Wallis nonparametric tests were used to compare the germline cell diameters between ploidy groups where the assumption of equal variances was violated (Sokhal and Rohlf, 1995). 


\section{Results}

\subsection{Seawater temperature}

The summer of 2003 was the hottest on record throughout much of Europe (Black and Sutton, 2007). As illustrated in Figure 2, the temperature of sea water recorded in 2003 at Belon-Rosbraz (i.e. very close to our study site) was higher than usual. Mean water temperature in August reached $22.4^{\circ} \mathrm{C}$ and was above $16^{\circ} \mathrm{C}$ (considered as the lower temperature in wich a complete maturation could be observed) (Chavez-Villalba et al., 2002b) from June to early September.

\subsection{Temporal dynamics of sex-ratio}

The temporal dynamics of sex-ratio were similar in the two groups (Figure 3). Both diploid and triploid oysters showed high rates of sexuate individuals from May to September 2003. A resting period (September to December 2004) of low sexual activity followed this period and a new reproductive cycle started in January 2004. The percentage of sexually differentiated individuals was not significantly higher in diploid oysters than in triploids over the total sampling period $(68 \%$ in the diploids v. $63 \%$ in the triploids).

There were no significant differences in mean sex-ratio when considering the whole study period, but diploid oysters included a higher percentage of males in summer 2003 (33 versus 15.7\%; P<0.05; between July $2^{\text {nd }}$ and September $1^{\text {st }}$ ) whereas the triploid group had more males in winter 2004 (16 versus $43 \% ; P<0.0001$; between January $26^{\text {th }}$ and March $22^{\text {nd }}$ ).

\subsection{Temporal dynamics of gonad stages}

The temporal dynamics of the percentage of individuals at the 5 defined reproductive stages (table 1 ) is presented in Figure 4. Although the general gonad maturation dynamics were simultaneous for the two types of oyster, triploids showed significantly higher percentages of individuals at early stages of gametogenesis during spring and summer 2003. Indeed, stages inferior to 3 (premature) represented $68.7 \%$ in diploids but $92.2 \%$ in triploids during spring $(P<0.0001)$, and $6.7 \%$ versus $53.6 \%$ in summer $(\mathrm{P}<0.0001)$. Surprisingly, a high proportion of triploids reached stages of maturation characterized by the presence of mature gametes. In July, $78.9 \%$ of the triploid oysters simultaneously showed gonias, maturing gametocytes and variable proportions of fully matured spermatozoids or oocytes (stage 2) whereas $95 \%$ of the diploid oysters were at stage 3 .

In the triploid group, between mid-July and early August, the percentage of maturing oysters (stage 2) decreased unless only a few reach stage 3 , and a majority of individuals $(68 \%)$ were found to be at stage 4 (reabsorbing stage). At this period, only a few diploids (5\%) were at stage 4.

Between August and September, the two groups included both ripe and spent individuals (stages 3 and 4), but by the end of September no individuals were found at the mature, pre-spawning stage. As expected, sexual activity was low in winter (i.e. samples were characterized by the predominance of stage 0) and a new reproductive cycle began as early as January 2004 for both groups.

\subsection{Condition index evolution and growth}

Whereas both groups showed similar DMW in May 2003, triploid oysters later reached significantly higher values $(P<0.0001)$ after a strong increase between May and June $19^{\text {th }}$. The differences between the two groups for DMW diminished and were not significantly different between June $2^{\text {nd }}$, and June $16^{\text {th }}$. This could correspond to partial spawning during this period, whereas the decrease recorded in August is related to the mass spawning detected by the analysis of the temporal $\mathrm{Cl}$ changes. Finally, DMW of triploid oysters decreased from $4.2 \pm 1.40 \mathrm{~g}$ in October to $2.63 \pm 0.94 \mathrm{~g}$ in December and then increased to reach $4.35 \pm 2.05 \mathrm{~g}$ in March 2004. Between November and February, DMW of diploid oysters decreased from $2.17 \pm 0.77 \mathrm{~g}$ to $1.57 \pm 0.56 \mathrm{~g}$ before increasing to $2.26 \pm 1.17 \mathrm{~g}$ in March. Although the high temporal variation in DMW and the relatively short length of our study do not allow us to build a growth model capable of comparing growth rate between the two groups, triploid oysters did show a higher growth potential. Triploid oysters showed an increase of 2.9 grams of their mean DMW between May 2003 and March 2004, compared with an increase of only 0.7 grams in diploid oysters.

As expected, the condition index $(\mathrm{Cl})$ of diploid oysters increased in spring during their gonad maturation (Figure 5a). A similar trend was also observed in triploid oysters. Mean $\mathrm{Cl}$ was only 
significantly higher in diploids than in triploids between May and September (812.6 \pm 231 in diploids versus $651.6 \pm 155 ; \mathrm{P}<0.05$ ). Following this period, $\mathrm{Cl}$ decreased to $459.2 \pm 131$ and $578.6 \pm 155$ in diploid and triploid oysters respectively. This decrease of $\mathrm{Cl}$ is characteristic of spawning. Histological analysis also revealed signs of spawning and germ cells resorption.

Although meat weight was not significantly different between the two groups in May 2003 (Fig. $4 \mathrm{~b})(1.56 \pm 0.44 \mathrm{~g}$ in diploid versus $1.46 \pm 0.59 \mathrm{~g}$ in triploid oysters; $\mathrm{P}>0.05)$, shell weight of triploids was heavier than that of diploid oysters $(40.53 \pm 9.48 \mathrm{~g}$ versus $24.17 \pm 6.12 \mathrm{~g} ; \mathrm{P}<0.0001)$ which suggests that allocation to shell growth could be higher in triploid oysters. This particular pattern of energy allocation was previously observed by Landau and Guo (1999) and Scarpa et al. (1996), and strongly contributed to the reduction of $\mathrm{Cl}$ in triploids compared with diploid oysters.

\subsection{Diameter of oocytic germline cells}

Measurement of cell diameter of the oocytic germ cells revealed some differences in gonad maturation between diploid and triploid oysters in the first sampling in June 2003. Average diameters were lower in triploid females $(P<0.0001)$, with a mean of $21 \pm 12$ versus $27 \pm 8 \mu \mathrm{m}$ in diploids (Figure 5 ) because of retarded maturation. According to Lango-Reynoso et al. (2000), this range of values, represents coexistence of mature oocytes with germline cells in ovo- and vitellogenesis in the follicles and is characteristic of early vitellogenesis. Variation in the cell diameters was however much greater in triploid females than in diploids $(P<0.0001)$, revealing a more heterogenous size distribution.

\section{Discussion}

\subsection{Comparative temporal dynamics of gametogenesis in diploid and triploid Pacific oysters}

Our results suggest that the initiation of gametogenesis was simultaneous in triploid and diploid oysters. Histological analyses show that the proliferation of gonias (stage 1) began as early as December 2003 in the two groups (Figure 4.). The percentage of sexually differentiated individuals was higher in triploid than in diploid oysters in January 2004 (65\% versus $45 \%$ respectively, non significant difference). The observed dynamic of gametogenesis of the diploid individuals was very similar to the one described by Enriquez-Diaz for diploid oysters in Marennes-Oleron Bay (EnriquezDiaz, 2004). Despite the fact that the first steps of gametogenesis appeared to be normally induced in triploids, the next stages were characterized by incomplete maturation with a high level of inter- and intra-individual variation. First, some triploid oysters presented retardation of the gametogenesis, remaining at early stages of maturation at a time when all diploid oysters had reached full gonad maturation (in June 2003,17\% of the triploids were at stage 1 whereas 100\% of the diploids were at stage 3). Second, the majority of the ripening triploid oysters simultaneously showed gonias, maturing gametocytes and variable proportions of fully matured spermatozoids or oocytes, exhibiting high intraindividual variation. Third, gametogenesis of some triploid oysters (5.6\% in June, to $31.6 \%$ in August) led to complete maturation of all their germline cells (i.e. stage 3). Finally, both diploid and triploid oysters showed evidence of spawning. Our results suggest that most triploid oysters show normal gametogenesis at the early stages (i.e. the proliferation of gonias at the beginning of the annual reproductive cycle) but not at later stages.

It remains unclear whether the long term persistence of gonias and immature cytes in triploid oysters was the result of temporal heterogeneity in maturation of primary germ cells within a single cohort or if this resulted from several successive cohorts of germ cells (see Fabioux et al., 2004 for diploid oysters). As early gametogenesis seemed to occur normally in these individuals, the partial sterility of triploid oysters may be a result of perturbation occurring during the differentiation of gonias to cytes.

The qualitative descriptors of gonad maturity used in the present study allowed us to compare the temporal dynamics of gonad maturation between diploid and triploid individuals; however, the use of these descriptors in triploid oysters raises some questions. The classification of reproductive stages was initially developed in Crassostrea gigas by Mann (1979). The classes were intended to describe gonad maturation of diploid bivalves in which the ultimate stage of gametogenesis is stage 3 , characterized by the maturity of an high proportion of germ cells. Triploid oysters rarely reach stage 3 , and early germline cells were found in the gonad tissues over a much longer period than in diploids. This suggests that the observed irregular gametogenesis, leading to a partial development of germ 
cells, is characteristic of the gametogenesis of triploid oysters. Our data also suggests that spawning can be observed in maturing triploids if the proportion of mature gametes is sufficient, even if some gonias or immature cytes subsist in the reproductive tissues (and led to the determination of stage 2 for these individuals). Consequently, stage 3 should not be considered as the ultimate stage of gonad maturation in triploid oysters because spawning is possible without reaching this stage.

Due to reduced sample size, short-term variations of sex-ratio along the reproductive period may not be significant and do not reflect changes in gender. The major interest of these results is to illustrate the similarity (or lack of discepancies) between the two groups. Indeed, the majority of diploid pacific oysters generally begin to reproduce as males (protandrous hermaphodit) and change to female during the following seasons of reproduction. Thus, determinism of gender in Crassostrea gigas is firstly under control of environmental factors mediated by physiological state. Consequently, as triploid individuals usually show contrasted physiological state compare to diploid ones due to different patterns of energetic allocation we were expected clear differences in sex-ratio like high rates of hermaphroditism, as noticed by authors in previous studies of reproduction for triploid Crassostrea gigas. Surprisingly, such discrepancies were unclear in this study. We can hypothesize that the differencies in gender determinism usually observed between diploid and triploid oysters are primarily due to perturbations of the reproductive function response to environmental forcing for triploid oysters. Here, it seems that reproductive processes occured quiet normaly for such oysters, and the similarities observed in sex determinism between the two ploidy goups must be linked to the "near-diploid" reproductive effort of the triploid individuals.

\subsection{Effect of environmental conditions on maturation of triploid oysters}

Temperature has been demonstrated to play a major role not only in the induction of gametogenesis but also in oocyte growth rate (i .e. the dynamics of maturation, Chavez-Villalba et al., 2002b). It is therefore likely that the exceptionally high water temperatures recorded during summer 2003 could have enhanced the reproductive effort in triploids by allowing an unusually high percentage of premature individuals to reach complete gonad maturation. This hypothesis could explain the high percentage of mature triploid oysters observed in our study, and is fully consistent with the results published by Shpigel et al. (1992), who showed that triploid C. gigas can achieve a full gametogenic cycle at elevated temperature (87\% of their triploid individuals were either spawned out or undergoing resorption after a 35-day exposure period at $30^{\circ} \mathrm{C}$ ). The elevated temperatures of summer $2003 \mathrm{might}$ not, however, be the only factor responsible for the very high proportion of ripening triploid oysters. In fact, triploid Pacific oysters are commonly cultured in areas warmer than Southern Brittany in other parts of the world, such as Australia and North America (Nell, 2002) without evidence of maturation such as that we describe here (Nell and Perkins, 2005; Allen and Downing, 1990). The high phytoplankton productivity of our study site could also have favoured the phenomenon, but more studies are needed to further examine the relative importance of environmental factors.

\subsection{Reproductive allocation in triploid oysters}

That the triploid oysters we monitored spawned during summer 2003 is supported by the strong decrease of their condition index and the observation of post spawning histological stages. Previous authors have reported spontaneous emissions of gametes by triploid oysters (Goulletquer et al., 1996; Shpigel, 1992; Allen and Downing, 1990), but this phenomenon remains poorly documented for oysters in natural conditions. Although our results are limited by the lack of quantitative data, the amount of emitted gametes inferred by the decrease in condition index was surprisingly high for triploid oysters. In our study, the presumed spawning corresponded to an average mass of $1.24 \mathrm{~g}$ of gametes per oyster, which represents a loss of $30 \%$ of the Dry Meat Weight (versus $1.22 \mathrm{~g}$ or $44.4 \%$ of DMW for the diploid oysters). The mean quantity of gametes emitted would therefore have been similar for the two groups, but it should be underlined that the triploid individuals were considerably heavier than the diploids (Figure $5 b$ ). We can therefore assume that triploid oysters would have shown a lower mean gamete production than diploid oysters at the same total size. In any case, our results suggest a much higher allocation to reproduction by triploid oysters than previously published studies: Guo and Allen (1994) and Gong et al. (2004) obtained estimates of $2 \%$ and $13.4 \%$ respectively for total egg number produced by triploid compare to diploid oysters. 


\subsection{Triploidy and genetic confinement of oysters}

The viability of the progeny of triploid oysters has been studied by crossing triploid genitors with diploid and triploid individuals. Gametes from triploids appeared to be fully viable but the progeny resulting from these crosses was mostly composed of aneuploids with a very low viability (Guo and Allen, 1994; Gong et al., 2004). Diploid, triploid and tetraploid offspring were also found in the progeny of these crosses (Guo and Allen, 1994). Overall, the viability of the progeny of triploid oysters was very low relative to diploids, ranging from 0.007 to $0.314 \%$, respectively for diploid (female) $x$ triploid (male), and triploid (female) $x$ diploid (male) crosses (Gong et al., 2004). These studies suggest that the potential for triploid Crassostrea gigas to produce viable progeny in the wild is low but not null. The relative fitness of triploid individuals is obviously much lower that of diploids, essentially because of the aneuploid nature of most of their progeny. Thus, triploidy should not be considered as a mean of genetic confinement in that species.

\section{Acknowledgements}

The authors thank Jean-Claude Martinez, Alain Le-Mercier, Christian Tartu and Alain Marhic, for the support they provided during the sampling. They are grateful to Yves-Marie Paulet, Denis Saulnier, Arnaud Huvet, Caroline Fabioux and Sophie De Decker for their helpful comments on this manuscript and to Stephane Guesdon for providing the environmental monitoring data. This work was supported by the CONCHPOL/RITMER (02 G 0534) grant, funded by the Ministère de la Jeunesse, de l'Education Nationale et de la Recherche (MJENR).

\section{References}

Allen, S. K. Jr. and Downing S. L., 1986. Performance of Triploid Pacific Oysters, Crassostrea gigas (Thunberg), I., Survival, growth, glycogen content, and sexual maturation in yearlings. J. Exp. Mar. Biol. Ecol., 102: 197-208.

Allen, S. K. Jr., Downing S. L., Chew K. K., 1989. Hatchery manual for producing triploid oysters. University of Washington Press, Seattle, Washington, USA, 27 pp.

Allen, S. K. Jr. and Downing S. L., 1990. Performance of Triploid Pacific Oysters, Crassostrea gigas : Gametogenesis. Can. J. Fish. Aquat. Sci., 47: 1213-1222.

Allen, S. K. Jr., Guo, X., Burreson, G., Mann, R., 1996. Heteroploid mosaics and reversion among triploid oysters, Crassostrea gigas. Fact or artifact. Journal of Shellfish Research, 15(2), 514 (abstract).

Allen, S. K. Jr., Howe, A., Gallivan, T., Guo, X., Debrosse, G., 1999. Genotype and environmental variation in reversion of triploid Crassostrea gigas to the heteroploid mosaic state. Journal of Shellfish Research, 18(1), 293 (abstract).

Black, E., Sutton R., 2007. The influence of oceanic conditions on the hot European summer of 2003. Climate dynamics 28(1), 53-66.

Chávez-Villalba, J., Barret, J., Mingant, C., Cochard, J.-C., Le Pennec, M., 2002a. Autumn conditioning of the oyster Crassostrea gigas: a new approach. Aquaculture, 210: 171-186.

Chávez-Villalba, J., Pommier, J., Andriamiseza, J., Pouvreau, S., Barret, J., Cochard, J.-C., Le Pennec, M., 2002b. Broodstock conditioning ot the oyster Crassostrea gigas: origin and temperature effect. Aquaculture, 214: 115-130.

Duchemin, M.B., Fournier, M., Auffret, M., 2007. Seasonal variations of immune parameters in diploid and triploid Pacific oysters, Crassostrea gigas (Thunberg). Aquaculture, 264: 73-81

Eudeline, B., 2004. La tétraploïdie chez les Mollusques Bivalves: Application à la production de triploïdes chez l'huître creuse Crassostrea gigas. Etude comparée de la gamétogenèse et des 
métabolismes associés chez les diploïdes, triploïdes et tétraploïdes. PhD thesis. Université de Rennes I, $183 \mathrm{p}$.

Enriquez-Diaz, M.R., 2004. Variabilité et bioénergétique de la reproduction chez l'huître creuse Crassostrea gigas. PhD thesis. Université de Bretagne Occidentale, $193 \mathrm{p}$.

Fabioux, C., Huvet, A., Le Souchu, P., Le Pennec, M., Pouvreau, S., 2005. Temperature and photoperiod drive Crassostrea gigas reproductive internal clock. Aquaculture, 250: 458-470.

Fabioux, C., Pouvreau, S., Le Roux, F., Huvet, A., 2004. The oyster vasa-like gene: a specific marker of the germline in Crassostrea gigas. Biochemical and Biophysical Research Communications, 315: 897-904.

Garnier-Géré, P., Naciri-Graven, Y., Bougrier, S., Magoulas, A., Héral, M., Kotoulas, G., Hawkins, A., Gérard, A., 2002. Influences of triploidy, parentage and genetic diversity on growth of the Pacific oyster Crassostrea gigas reared in contrasting natural environments. Molecular Ecology, 11: 14991514.

Gong N, Yang H, Zhang G, Landau B J,.Guo X, (2004) Chromosome inheritance in triploid Pacific oyster Crassostrea gigas Thunberg, Heredity, 93: 408-415.

Goulletquer, P., Joly, J.-P., Gérard, A., Le Gagneur, E., Moriceau, J., Peignon, J.-M., Heurtebise, S., Phélipot, P., 1996. Performance of triploid Pacific Oysters Crassostrea gigas (Thunberg) reared in high carrying capacity ecosystem: survival, growth and proximate biochemical composition. Haliotis, 25: 1-12.

Guo, X. and Allen, S.K. Jr., 1994. Reproductive Potential and Genetics of Triploid Pacific Oysters, Crassostrea gigas (Thunberg). Bio. Bull., 187: 309-318.

Hawkins, A. J. S., Magoulas, A., Héral, M., Bougrier, S., Naciri-Graven, Y., Day, A. J., Kotoulas, G., 2000. Separate effects of triploidy, parentage and genomic diversity upon feeding behaviour, metabolic efficiency and net energy balance in the Pacific oyster Crassostrea gigas. Genet. Res. Camb., 76: 273-284.

Honkoop, P.J.C., 2003. Physiological costs of reproduction in the Sydney rock oyster Saccostrea glomerata. How expensive is reproduction ? Oecologia, 135: 176-183.

Kooijman, S.A.L.M., 2000. Dynamic energy and mass budgets in biological systems. Cambridge University Press, Cambridge, $424 \mathrm{p}$.

Landau, B., and Guo, X., 1999. Growth characteristics in triploid Pacific oysters - a new dimension. J. Shellfish Research 18: 270-271.

Lango Reynoso, F., Chavez-Villalba., J., Cochard, J. C., Le Pennec, M., 2000. Oocyte size, a means to evaluate the gametogenic development of the Pacific oyster, Crassostrea gigas (Thunberg). Aquaculture, 190: 183-199.

Mann, R., 1979. Some biochemical and Physiological aspects of growth and gametogenesis in Crassostrea gigas and Ostrea edulis grown at sustained elevated temperature. J. Mar. Biol. Ass. U.K., 59: 95-110.

Nell, J.A. and Perkins B., 2005. Studies on triploid oysters in Australia : farming potential of all-triploid Pacific oysters, Crassostrea gigas (Thunberg), in Port-Stephens, New South Wales, Australia. Aquaculture Research, 36: 530-536.

Nell, J.A., 2002. Farming triploid oysters. Aquaculture, 210: 69-88.

Pouvreau, S., Bourles, Y., Lefebvre, S., Gangnery, A., Alunno-Bruscia, M., 2006. Application of a dynamic energy budget model to the Pacific oyster, Crassostrea gigas, reared under various environmental conditions. Journal of Sea Research, 56 (2): 156-167. 
Ren, J.S. and Ross, A.H., 2001. A dynamic energy budget model of the Pacific oyster Crassostrea gigas. Ecological Modelling, 142: 105-120.

Shpigel, M., Barber, B.J., Mann, R., 1992. Effects of elevated temperature on growth, gametogenesis, physiology, and biochemical composition in diploid and triploid Pacific oysters, Crassostrea gigas Thunberg. J. Exp. Mar. Biol. Ecol., 161: 15-25.

Scarpa, J., Sturmer, L., Quesenbury, E., Longley, R., and Vaughan, D., 1996. Performance of triploid oysters Crassostrea virginica, grown by project OCEAN participants. J. Shellfish Research, 15: 512513.

SPSS InC., 1999. SYSTAT ${ }^{\circledR} 9$ Statistics I. SPSS InC., 660 p.

Sokhal, R.R., and Rohlf, J.F., 1995. Biometry: the principles and practises of statistics in biological research, third edition. W.H. Freeman and company, $887 \mathrm{p}$.

Utting, S.D., and Child, A., 1994. Genetic manipulation of the Manila clam (Tapes philippinarum) using cytochalasin B to induce triploidy. Aquaculture, 44: 133-144. 
Table 1: Classification of reproductive stages based on Mann (1979) and Lango-Reynoso (2000)

\begin{tabular}{|c|c|}
\hline Stage & Histological description \\
\hline 0 (resting stage) & $\begin{array}{l}\text { No trace of sexuality; follicles are non-existent or elongated and } \\
\text { consist of undifferentiated germinal epithelium. }\end{array}$ \\
\hline 1 (early growth stage) & $\begin{array}{l}\text { Follicles are small and isolated with numerous spermatogonia or } \\
\text { oogonia. }\end{array}$ \\
\hline 2 (late growth stage) & $\begin{array}{l}\text { Follicles are actively developing with primary gametocytes and } \\
\text { some free (secondary) spermatozoa and oocytes. }\end{array}$ \\
\hline 3 (mature) & $\begin{array}{l}\text { Near ripe or ripe follicles, densely packed with maturing gametes; } \\
\text { presence of mature gametes. }\end{array}$ \\
\hline $\begin{array}{l}4 \text { (spawning and } \\
\text { reabsorbtion stages) }\end{array}$ & Follicles distended, numerous gametes remain. \\
\hline
\end{tabular}




\section{Figures}

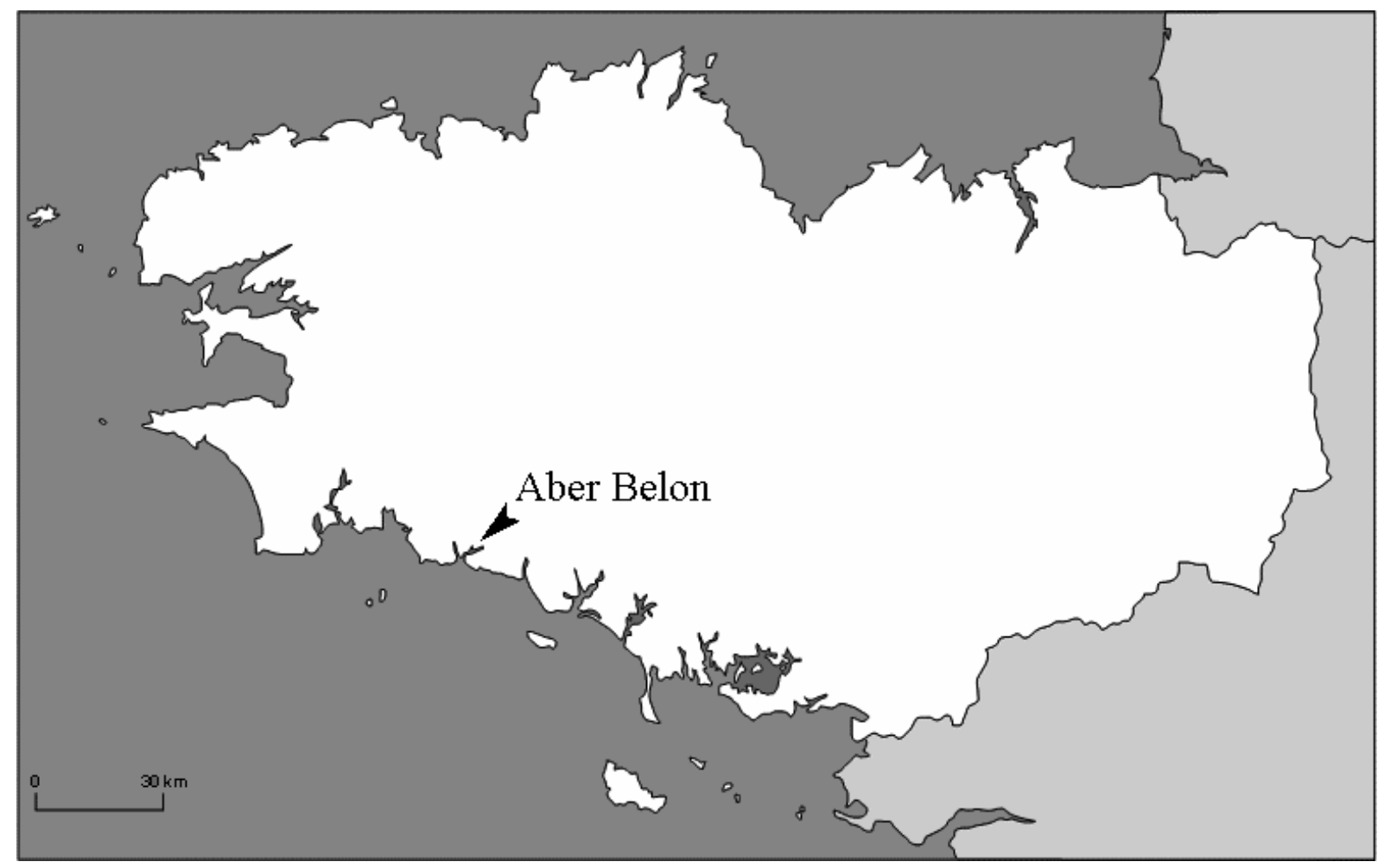

Figure 1: Localization of the sampling site. 


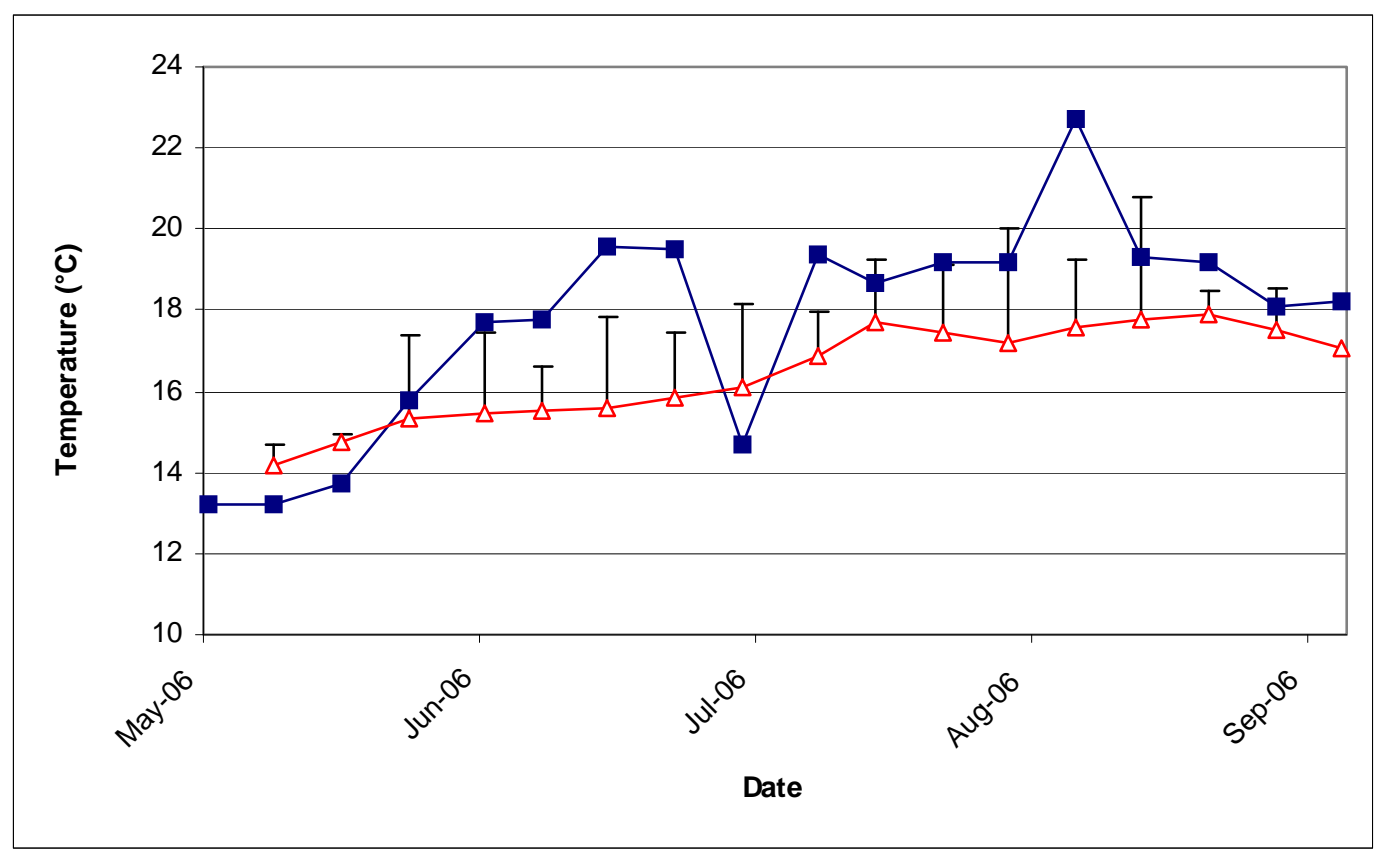

Figure 2: Seawater temperature in 2003 (") and mean and the coefficient of variation for 1994-2002 $(\Delta)$.

a

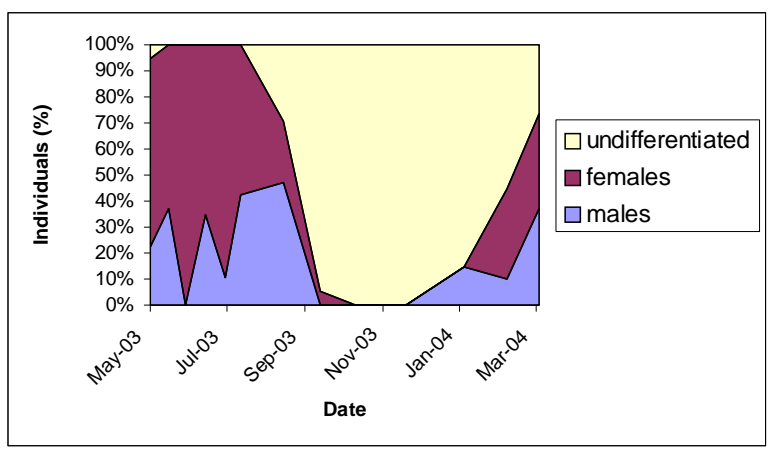

b

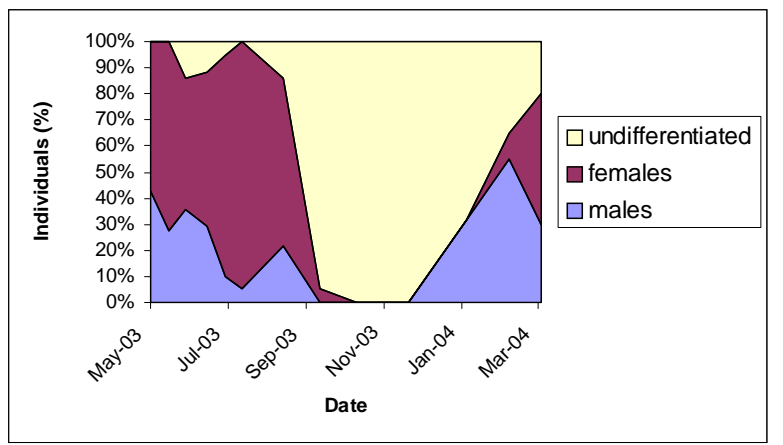

Figure 3: Percentage of males, females and undifferentiated individuals from May 2003 to March 2004 in the diploid (a) and triploid (b) groups ( $\mathrm{n}=20$ individuals/group/sampling point). 
a

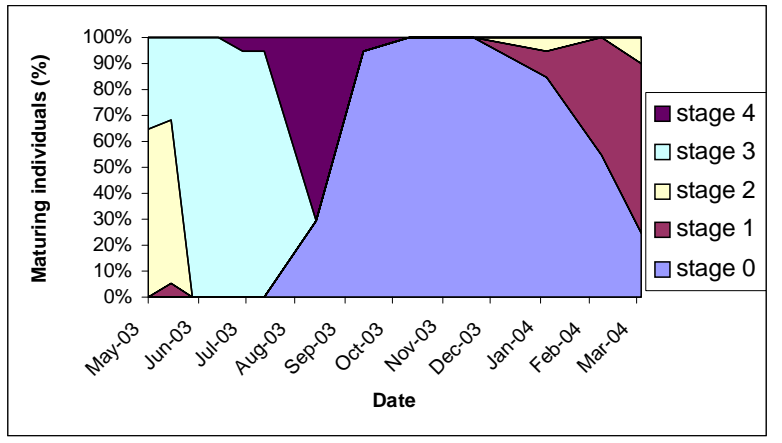

b

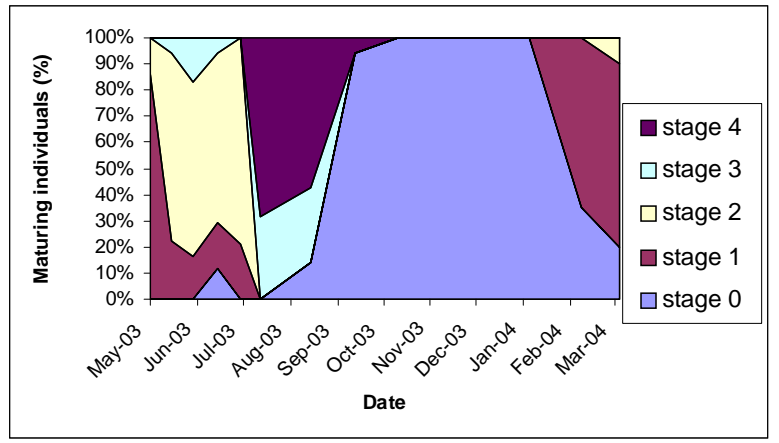

Figure 4: Percentage of individuals observed at stages 0 (resting stage) to 4 (spawning and reabsorbing stages) from May 2003 to March 2004 in the diploid (a) and triploid (b) groups ( $n=20$ individuals/ group/sampling point).

a

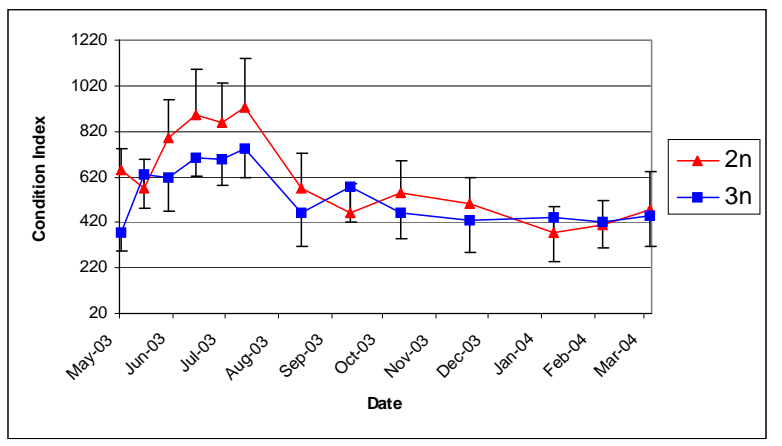

b

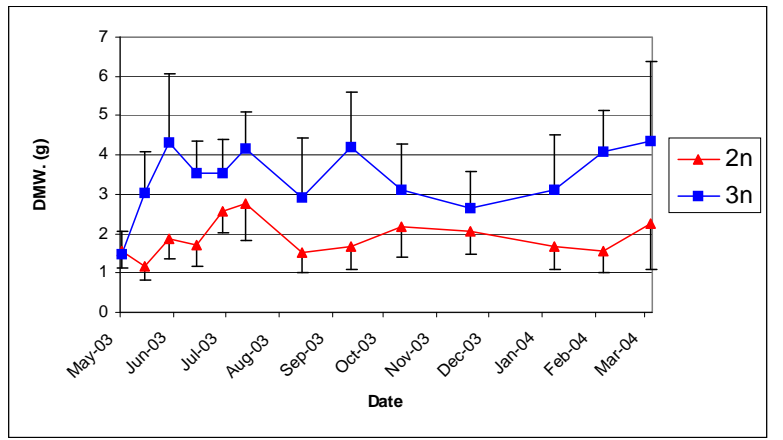

Figure 5: Mean and coefficient of variation of (a) condition index and (b) dry meat weight (in grams) of diploid (red triangles) and triploid (blue squares) oysters from May 2003 to March 2004 ( $n=30$ individuals/ group/sampling point). 
a

diameter of germline cells $(\mu \mathrm{m})$

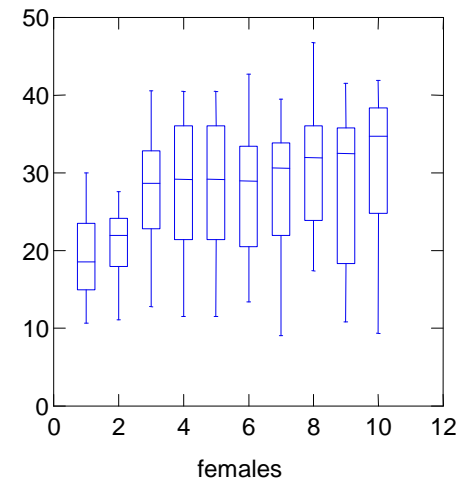

b

diameter of germline cells $(\mu \mathrm{m})$

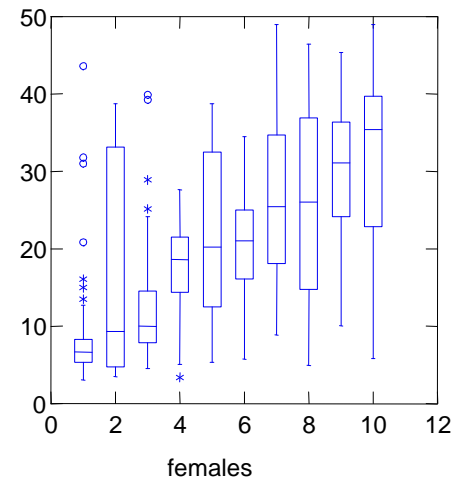

Figure 6: Within-individual variation of the diameter of the oocytic germline cells, sized for ten individuals in June (a) in diploids and (b) in triploids. 